\title{
Иммуногенетические предикторы раннего прерывания беременности
}

Татаркова Е.*, Тугуз А., Шумилов Д.

Адыгейский государственный университет, НИИ Комплексных проблем, Майкоп, Россия

*e-mail:warmwild@yandex.ru

Ключевые слова: цитокины, SNP, SLC19A1, IL-1 $\beta$, TNF- $\alpha$, IL-12B

Мотивация и иель: Высокая смертность и социально-экономический ущерб от репродуктивных потерь в Российской Федерации обусловливает необходимость выявления молекулярногенетических маркеров, вовлеченных в патогенез угрозы выкидыша $[1,2]$. В связи с этим работа направлена на установление полиморфизмов генов-маркеров, ассоциированных с развитием угрозы выкидыша в I триместре беременности для жительниц Республики Адыгея (РА).

Meтоды и алгоритмы: В обследованной группе 58 жительниц РА $(28,5 \pm 5,7$ года) с диагнозом угрозы прерывания беременности в срок до 13 нед.; в контроле - здоровые женщины $(n=51$; $28,4 \pm 5,97$ года). Использованы методы: ПЦР с электрофоретической детекцией результатов (НПФ «Литех», Россия) и в режиме Real-Time («Генетика метаболизма фолатов», ООО «ДНКтехнология», Россия); ИФА с использованием коммерческих тест-систем ООО «Цитокин» (СанктПетербург, Россия). МНК выделены по методу А. Воуum (1968). Статистические расчеты проведены с использованием пакета прикладных программ SPSS Statistics 17.0 (Inc., Chicago, USA) и Office Excel 2016 (Microsoft).

Результаты: С угрозой раннего прерывания беременности у жительниц РА ассоциированы: гетерозиготный генотип G80A гена транспортера фолатов SLC19A1 (OR $=4,11 ; 95 \%$ CI = 1,39$12,18 ; \mathrm{p}=0,02)$, «мутантная» -511Т аллель гена медиатора острого воспаления IL-1 $\beta(\chi 2=16,96 ; \mathrm{p}=$ $0,00004 ; \mathrm{OR}=5,8)$, гетерозиготный C511T и гомозиготный T511T генотипы гена IL-1 $\beta$, повышающие риск осложнения беременности в первом триместре соответственно в 3,5 и 5,7 раз ( $\chi 2$ $=14,81 ; \mathrm{p}=0,0006)$, а также $-1188 \mathrm{C}$ аллельный вариант гена регуляторного IL-12B $(\chi 2=6,17 ; \mathrm{p}=$ $0,01 ; \mathrm{OR}=2,97)$. Гетерозиготный генотип C511T промоторного региона гена острого воспаления IL-1 $\beta(\mathrm{p}=0,032)$ и гомозиготный «нормальный» генотип G308G плейотропного цитокина TNF- $\alpha$ (p $=0,045)$ определяют уровни продукции и соотношение медиаторов воспаления, участвующих в формировании фетоплацентарного комплекса, и являются генетическими предикторами угрозы ранних гравидарных потерь.

Заключение и доступность: Генетически детерминированная оверэкспрессия IL-1 $\beta$ и снижение продукции TNF- $\alpha$, выявленные в экспериментах in vitro при оценке стимулированной продукции цитокинов МНК в группе женщин с угрозой раннего прерывания беременности, подтверждают ведущую роль медиаторов воспаления «первой волны» в патогенезе репродуктивных осложнений.

Список литературы

1. Гордеева Л.А. и др. Ассоциации полиморфизма генов цитокинов с невынашиванием беременности. Медищинская иммунология. 2017;19(5):585-596.

2. Николаева А.Е. и др. Ретрохориальная гематома как фактор риска возникновения гематологических осложнений беременности. Вестник гематологии. 2018;XIV(1):22-27. 